\title{
PERJALANAN REFORMA AGRARIA BAGIAN DARI AMANAH KONSTITUSI NEGARA
}

\author{
Setiyo Utomo \\ Fakultas Hukum Universitas Mulawarman, Samarinda \\ email: setiyoutomo@fh.unmul.ac.id
}

disampaikan 29/6/2020 - di-review 8/12/2020 - diterima 31/5/2021

DOI: $10.25123 /$ vej.v7i1.3935

\begin{abstract}
Abstrack
The author examines and describes how agrarian reform is realized during different government periods. To do that, policy, and legal documents, directly or indirectly related to agrarian reform, is analysed. This research reveals that attempt at agrarian reform up to present is focussed developing policies aiming to restructure land ownership and utilization (land reform). Another finding is that the promulgation of Law No. 11 of 2020 (Law on Job Creation) tends to shift the focus more on granting easy access to land for development purposes. This change of policy priority will have dire consequence to access to land for the poor and most likely increase agrarian conflicts.
\end{abstract}

Keywords: Agrarian-Land Reform, inequality in access to land, agrarian conflict.

\begin{abstract}
Abstrak
Penelitian ini menelusuri realisasi reforma agraria dari masa pemerintahan yang berbeda. Untuk itu ditelaah dokumen kebijakan dan peraturan hukum yang langsung tidak langsung berkenaan dengan reforma agraria. Kajian yang dilakukan mengungkap bahwa reforma agraria yang masih terus berlangsung diwujudkan melalui, antara lain, penataan penguasaan-pemilikan dan pemanfaatan tanah (land reform). Temuan lain adalah adanya ancaman terhadap keberlanjutan reforma agraria dengan lahirnya UU No. 11 tahun 2020 (UU Cipta Kerja) yang justru memberi tekanan pada penguasaan-pengelolaan ruang untuk kepentingan pembangunan. Perubahan prioritas kebijakan terhadap penataan penguasaan-pemilikan tanah ini justru akan menghambat akses rakyat kecil pada tanah dan meningkatkan konflik agraria.

Kata Kunci:

Reforma Agraria, Ketimpangan askes tanah, konflik agraria.
\end{abstract}

\section{Pendahuluan}

Bagi bangsa Indonesia keberadaan tanah merupakan salah satu karunia yang maha kuasa yang terdapat di dalam alam semesta oleh karena itu tanah tidak dapat dipisahkan juga oleh masyarakat bangsa Indonesia yang hubungan tersebut bersifat mutlak. Untuk meningkatkan kesejahteraan masyarakat Indonesia diperlukan juga arah kebijakan yang mengatur mengenai pengelolaan tanah dan hak-hak atas tanah. Kebijakan yang dibuat oleh pemerintah memiliki tujuan untuk kesejahteraan masyarakat yang berkelanjutan sebagamana pada program land reform bahkan keseluruhan program agraria reform (reforma agraria) disebut 
program land reform sehingga muncul sebutan land reform dalam arti sempit dan land reform dalam arti luas. ${ }^{1}$ Tujuan diadakannya land reform adalah untuk menyempurnakan adanya pemerataan tanah bagi masyarakat yang belum mendapatkan tanah. Terdapat dua dimensi untuk menyempurnakan land reform yaitu pertama adanya usaha untuk menciptakan pemerataan hak atas tanah diantara para pemilik tanah melalui usaha dengan redistribusi tanah, kedua adalah mengurangi perbedaan pendapatan antara petani besar dan kecil yang merupakan usaha untuk memperbaiki pendapatan petani secara menyeluruh untuk meningkatkan dan memperbaiki daya guna penggunaan tanah. ${ }^{2}$

Pada masa pergantian presiden di Indonesia mulai dari orde lama, orde baru hingga ke era reformasi memiliki beberapa perbedaan dalam hal pelaksanaan reforma agraria. Periode kedua kepemimpinan Joko Widodo dengan mendorong land reform dan kepemilikan 9 jt hektar masih terus berlangsung hingga saat ini. Kebijakan reforma agraria sebagai bagian dari pembangunan nasional dapat dijadikan dasar pula untuk kebijakan ekonomi nasional melalui upaya pemerataan, pengurangan kesenjangan, penanggulangan kemiskinan serta penciptaan lapangan kerja di pedesaan. Reforma agraria yang berfungsi untuk memperkuat pemilikan tanah untuk seluruh rakyat Indonesia terutama masyarakat yang tak punya tanah baik yang tinggal di pedesaan, pinggir-pinggir hutan, pesisir-pesisir pantai, pulau-pulau kecil, maupun di lereng-lereng pegunungan. ${ }^{3}$

Pentingnya keberadaan tanah merupakan suatu objek yang dibutuhkan oleh banyak orang terutama dalam kegiatan yang ada di lingkungan sehari-hari namun tanah yang tidak bertambah sedangkan masyarakat yang semakin bertambah sehingga menimbulkan sengketa konflik agraria. Persentase persebaran konflik hingga tahun 2020 tentunya belum secara final terdata dalam skala nasional namun konflik agraria dapat dilihat dengan kasus yang terjadi di tahun 2019 sebagaimana dalam catatan akhir tahun 2019 yang dirangkum oleh konsorsium pembaharuan agraria (KPA) bahwa telah terjadi 279 letusan konflik

\footnotetext{
Budi Harsono, Hukum Agraria Indonesia, Sejarah Pembentukan UUPA, Isi Dan Pelaksanaannya, Jilid I, Citra Aditya Bakti, Bandung, 2003, hlm 203

2 Supriadi, Hukum Agraria, Sinar Grafika, Jakarta, 2007, hlm 72

3 Siti Chadijah, Dwi Kusumo Wardhani, and Ali Imron, Kebijakan Reforma Agraria Terhadap Lahan Pertanian Di Kabupaten Tulungagung, JCH (Jurnal Cendekia Hukum), Nomor 1, Volume 6, hlm : 91-103, September 2020
} 
agraria dengan luasan wilayah konflik mencapai 734.239,3 hektar. Jumlah masyarakat terdampak konflik agraria tahun ini sebanyak 109.042 KK yang tersebar di 420 desa, di seluruh provinsi di tanah air. Sengketa konflik agraria tahun lalu yaitu 410 letusan konflik sehingga terjadi penurunan jumlah letusan konflik agraria di tahun ini. Namun apabila dilihat dari eskalasi kekerasan penanganan konflik agraria pada jumlah korban dan masyarakat yang ditangkap karena mempertahankan haknya atas tanah tersebut maka konsorsium pembaharuan agraria (KPA) mencatat pada tahun 2020 adanya peningkatan yang menghawatirkan dalam hal brutalita aparat di wilayah-wilayah konflik agrarian. Dalam rangka mengatasi persebaran konflik agraria tentunya menjadi bagian yang harus diselesaikan oleh Negara baik dalam kebijakan hingga teknis dilapangan pada saat menangani konflik agraria. Peran pemerintah dalam meminimalisir konflik agraria dengan adanya kebijakan pada program percepatan reforma agraria melalui penataan aset dan akses. Reforma agraria yang dicita-citakan di era sukarno seharunya memberikan gambaran untuk setiap kebijakan yang akan dilaksanakan oleh pemerintah dalam melaksanakan reforma agraria secara tuntas.

Berdasarkan penjelasan yang telah dikemukan di atas bahwa hingga saat ini pelaksanaan reforma agraria masih terus berlanjut. Pada kenyataannya bahwa masih terjadinya ketimpangan kepemilikan lahan dan konflik agraria yang merupakan bagian dari objek reforma agraria dan seharusnya pelaksanaan reforma agraria sudah mendapat gambaran atas perjalanan reforma agraria yang begitu panjang sehingga pelaksanaan reforma agraria dapat terselesaikan bukan menambah persebaran atas konflik agraria. Pada pokok persoalan yang dibahas dalam artikel ini adalah perjalanan reforma agraria yang sampai saat ini belum terselesaikan sebagaimana di era pemerintahan sukarno hingga Joko Widodo. Reforma agraria yang sedang berlangsung dengan cara mendorong land reform dan program kepemilikan tanah 9 juta hektar masih terus berlanjut di periode kedua Joko Widodo dan Lahirnya Undang-Undang Nomor 11 Tahun 2020 Tentang Cipta Kerja (Omnibus Law) memberikan penafsiran tersendiri terhadap keberlangsungan atas reforma agraria. Untuk itu terdapat beberapa hal yang perlu diteliti lebih dalam (1) kebijakan pelaksanaan reforma agraria sebagai bagain 
untuk mengatasi ketimpangan kepemilikan lahan (2) apa yang menjadi hambatan reforma agraria yang masih terus berlangsung hingga saat ini?.

Metode yang digunakan dalam tulisan ini adalah metode penelitian yuridis normatif atau penelitian hukum doktrinal. Peneltiian yuridis normatif terdiri dari Pendekatan perundang-undangan (statute approach) dan pendekatan konseptual. Pendekatan Undang-Undang (statute approach) dilakukan dengan menelaah semua undang-undang dan regulasi yang bersangkut paut dengan isu hukum yang sedang ditangani. ${ }^{4}$ Sedangkan pendekatan konseptual dilakukan dengan mempelajari pandangan-pandangan dan doktrin di dalam ilmu hukum, peneliti akan menemukan ide-ide yang melahirkan pengertian-pengertian hukum, konsepkonsep hukum, dan asas-asas hukum yang relevan dengan masalah yang dihadapi. ${ }^{5}$

\section{Pembahasan}

\section{Reforma Agraria Dari Masa Sukarno Hingga Joko Widodo}

Permulaaan reforma agraria pada masa sukarno dengan meletakkan dasar penataan agraria, land reform atau juga sering disebut reforma agraria (RA) sebuah konsep dan gagasan besar mengusung misi yang tidak sederhana, reforma agraria hadir sebagai wujud dari pengejawantahan Undang-Undang Nomor 5 Tahun 1960 tentang Peraturan Dasar Pokok-Pokok Agraria (UUPA) yaitu memuat amanah konstitusi pasal 33 Undang-Undang Dasar Negara Republik Indonesia Tahun 1945. ${ }^{6}$ Pelopor reforma agraria tidak hanya Sukarno dan Muhammad Hatta di bawah kepemimpinannya pada tahun 1926 bahwa Perhimpunan indonesia diproklamasikan di Belanda penghapusan tanah milik pribadi di Hindia Belanda maka setelah kembali ke tanah air, Hatta memulai untuk fokus pada kedaulatan rakyat dan dianalisis itu tanah masa jabatan sistem yang hasil itu diterbitkan dalam beberapa edisi Daulat Koran Ra'jat tahun 1930-an di bawah panitia adat (komite adat) dalam bahasa Jepang era. Muhammad Hatta sebagai konseptor Pasal 33 Undang-Undang Dasar Negara Republik Indonesia Tahun 1945 yang

Zainuddin Ali, Metode Penelitian Hukum, Sinar Grafika, Jakarta , 2011, hlm. 105

M. Syamsudin, Operasionalisasi Penelitian Hukum, Rajagrafindo Persada, Jakarta 2007, hlm. 60.

M Nazir Salim and Westi Utami, Reforma Agraria, Menyelesaikan Mandat Konstitusi: Kebijakan Reforma Agraria Dan Perdebatan Tanah Objek Reforma Agraria, STPN Press, Yogyakarta 2020, hlm. 32 
mengusulkan pada kebijakan mengenai sistem pembatasan hak kepemilikan tanah sampai dengan 5 hektar dengan melalui proses yang panjang sebagaimana tujuannya yaitu dikeluarkannya dan disahkannya Undang-Undang Nomor 5 Tahun 1960 tentang Prinsip Dasar Agraria Pokok-Pokok Agraria (UUPA). ${ }^{7}$

Keberadaan Undang-Undang Pokok Agraria hingga saat ini membuktikan bahwa produk hukum yang dihasilkan pada masa pemerintahan sukarno masih sangat relevan dengan kondisi saat ini untuk dijadikan dasar hukum setiap pelaksanaan yang bersumber pada pokok-pokok agraria. Undang-Undang Pokok Agraria bukan hanya memuat ketentuan-ketentuan mengenai perombakan hukum agraria namun Undang-Undang Pokok Agraria juga memuat persoalan lain dan penyelesaiannya sesuai dengan situasi dan kondisi keagrariaan di Indonesia dan tujuan akan mewujudkan masyarakat adil dan makmur berdasarkan Pancasila yang pada waktu itu disebut sosialisme Indonesia, agraria reform Indonesia meliputi 5 (lima) pogram yaitu : pertama, pembaharuan hukum agraria melalui unifikasi hukum yang berkonsepsi nasional dan pemberian jaminan kepastian hukum, kedua, penghapusan hak-hak asing dan konsesi kolonial atas tanah, ketiga, menghakhiri penghisapan feudal secara berangsung-angsur, keempat, perombakan pemilikan dan penguasaan tanah serta hubungan-hubungan hukum yang bersangkutan dengan pengusahaan tanah dalam mewujudkan pemerataan kemakmuran dan keadilan, kelima, perencanaan persediaan dan peruntukan bumi, air, dan kekayaan alam yang terkandung di dalamnya serta penggunaannya secara terencana,sesuai dengan daya dukung dan kemampuannya. ${ }^{8}$

Lahirnya orde baru pada masa pemerintahan Suharto dengan menerbitkan UU Penanaman Modal Asing, UU Pokok Kehutanan, dan UU Pertambangan yang berbeda nafas dengan UUPA karena mementingkan semangat pembangunan yang berbasis modal asing dengan kebijakan pemberian konsesi lahan secara luas "menghidupkan" warisan kolonial domein verklaring, dan kembali mengesahkan eksploitasi sumber daya alam secara bebas, mengeksklusi masyarakat dari lahan

7 Retor A W Kaligis, Agrarian Reform As A Nationalism Issue From Colonial To Reformasi Era, Paramita: Historical Studies Journal, Volume 29, Nomor 1, hlm 28-42, Maret 2019.

8 Budi Harsono, supra no 1, hlm 245 
dan penghidupannya. ${ }^{9}$ Sejak orde baru masa Suharto yang berkuasa selama 32 tahun melakukan perubahan yang orientasi kebijakan agraria dengan memprioritaskan tanah dalam kebijakan pembangunan yaitu pembangunan pertanian, industri, dan pembangunan prasarana umum sehingga julukan Suharto yang melekat hingga saat ini pun adalah bapak pembangunan. Jatuhnya Suharto pada tahun 1988 dengan ditandainya era reformasi dan munculnya gerakan agraria yang digaungkan oleh B.J Habibie dengan menghidupkan isu land reform. Jatuhnya Suharto dan berbagai peristiwa chaos di daerah dan berbagai kerusuhan di daerah akibat peristiwa politik juga rentetan kekerasan anti tionghoa di berbagai kota yang menyebabkan kelumpuhan sistem ekonomi, keamanan, dan pemerintahan. Pasca kerusuhan di kota dilanjutkan dengan berbagai peristiwa reclaiming tanah-tanah HGU, khususnya di Jawa, Sumatera, Kalimantan, dan Makassar. ${ }^{10}$ Wacana reforma agraria kembali hadir menjadi perbincangan publik setelah tumbangnya orde baru di tahun 1998 atau biasa disebut periode reformasi. Isu reforma agraria kembali menjadi perdebatan publik pasca kejadian pada bulan Mei tahun 1998 yaitu terjadi reclaiming tanah secara dramatik yang menyebar dimana-mana antara lain Jawa Timur, Jawa Barat, Sumatera dan Indonesia bagian timur yang saat ini banyak ribuan petani bergerak menuntut agar tanah-tanah yang dulu diambil oleh negara untuk berbagai kepentingan pembangunan agar dikembalikan kepada petani. ${ }^{11}$

Keinginan para petani untuk mengambil lahan yang selama ini dikuasai oleh korporasi mendapat protes, penjarahan, dan kekerasan lainnya sehingga tuntutan rakyat yaitu dilaksanakannya reforma agraria di tahun 1998 dengan menekan pemerintah agar memprioritaskan terkait penataan struktur penguasaan tanah yang memiliki ketimpangan serta menyelesaikan konflik agraria yang terjadi. Tuntutan agar dilaksanakan reforma agraria ini belangsung sepanjang 1999-2001 yang pada puncaknya ketika MPR mengeluarkan TAP MPR No. IX Tahun 2001 tentang Pembaruan Agraria dan Pengelolaan Sumber Daya Alam. Reforma agraria dengan lahirnya TAP MPR memberikan bukti atas sejarah baru

9 Noer Fauzi, Land Reform Dari Masa Ke Masa, Tanah Air Beta, Yogyakarta, 2012, hlm. 106

10 M Nazir Salim and Westi Utami, supra no 6, hlm. 4

11 Boedhi Wijardjo dan Herlambang Perdana, Reklaiming dan Kedaulatan Rakyat, YLBHI, 2001, hlm. 6 
terhadap pengelolaan sumber daya alam sehingga adanya TAP MPR memberikan dasar untuk memberikan perubahan kebijakan agraria Indonesia dengan tidak ada kaitannya dalam simpatisan komunis.

Pasca lahirnya TAP MPR reforma agrarian sepanjang pemerintahan Gus Dur dan Megawati, tidak banyak yang dihasilkan dalam menyelesaikan persoalan agraria. Namun dalam periode ini dengan lahirnya TAP MPR IX/2001 tidak banyak hal baru yang dilahirkan pada periode tersebut sehingga pasca Timor-Timor lepas lalu Papua bergejolak Gus Dur yang pada saat itu lebih banyak fokus menangani hubungan internasional dan menyelematkan kondisi ekonomi yang terpuruk akibat krisis di tahun 1998. ${ }^{12}$ Reforma agraria yang diusung oleh rezim Susilo Bambang Yudhoyono dibawah komando Joyo Winoto dengan menguatkan target redistribusi tanah 8-9 juta hektar yang bersumber pada tanah objek reforma agraria (TORA) berupa Kawasan Hutan, HGU, tanah terlantar dan tanah lain bekas hak namun pada praktifknya Susilo Bambang Yudhoyono tidak mampu mengendalikannya. ${ }^{13}$ Padamasa pemerintahan Susilo Bambang Yudhoyono selama 2 periode hanya terfokus pada persoalan administrasi dengan kebijakan legalisasi aset dan redistribusi tanah kepada masyarakat. Pasca lahirnya Undang-Undang Nomor 2 Tahun 2012 tentang Pengadaan Tanah maka semakin kental untuk diadakannya pengadaan tanah dalam hal pembangunan yang mengarah pada proyek pembangunan dengan upaya yang dilakukan untuk menyelesaikan konflikkonflik agraria. Namun upaya yang dilakukan juga tidak mampu menjawab bagaimana maraknya konflik agraria di daerah yang diakibatkan dari pembiaran kebijakan dari periode-periode sebelumnya. ${ }^{14}$ Pada masa Susilo Bambang Yudhoyono sebelum berakhirnya masa jabatan terdapat satu momentum penting telah dilahirkan oleh Aliansi Masyarakat Adat Nusantara (AMAN), Kesatuan Masyarakat Hukum Adat Kenegerian Kuntu, Kabupaten Kampar, Provinsi Riau, dan Kesatuan Masyarakat Hukum Adat Kasepuhan Cisitu, Kabupaten Lebak, Provinsi Banten, Juga didukung oleh aktivis, dan NGO. Pada bulan Maret tahun 2012 secara resmi kelompok ini mengajukan gugatan ke Mahkamah Konstitusi terkait Undang-

12 M Nazir Salim and Westi Utami, supra no 6, hlm 25

13 Id, hlm 36

14 Widiyanto, Potret Konflik Agraria Di Indonesia, BHUMI: Jurnal Agraria Dan Pertanahan, Volume 1, Nomor 37, hlm. 15-27, April 2013. 
Undang Nomor 41 tahun 1999 tentang Kehutanan yang diindikasi banyak merugikan masyarakat khususnya masyarakat adat dan hasil guugatan AMAN sebagian ditolak dan sebagian dikabulkan oleh Mahkamah Konstitusi. 15

Pasca berakhirnya pemerintahan Susilo Bambang Yudhoyono maka dimulainya reforma agraria periode Joko Widodo-Jusuf kalla yang dalam lintasan sejarah reforma agraria cukup banyak mengalami perubahan dan tafsiran atas praktiknya terkait pelaksanaan reforma agraria yang disesuaikan dengan perkembangan zaman serta negara yang menerapkannya. Indonesia sendiri pernah mencita-citakan reforma agraria yang ideal yaitu penataan struktur penguasaan yang berkeadilan sebagaimana diyakini oleh Sukarno dalam pidatopidato menjelang disahkannya Undang-Undang Pokok Agraria untuk melaksanakan land reform merupakan bagian mutlak dari revolusi Indonesia".16 Program reforma agraria diawal masa pemerintahan Joko Widodo-Jusuf Kalla tercantum dalam Peraturan Presiden Nomor 45 Tahun 2016 tentang Rencana Kerja Pemerintah Tahun 2017 yang memuat 5 (lima) program prioritas yakni, pertama, penguatan kerangka regulasi dan penyelesaian konflik agraria, kedua, penataan penguasaan dan pemilikan tanah obyek reformaagraria, ketiga, kepastian hukum dan legalisasi hak atas tanah obyek reforma agraria, keempat, pemberdayaan masyarakat dalam penggunaan, pemanfaatan dan produksi atas tanah obyek reforma agraria, kelima, kelembagaan pelaksana reforma agraria pusat dan daerah. ${ }^{17}$ Masa pemerintahan Joko Widodo-Jusuf Kalla memberikan pesan utama dalam rapat kabinet terbatas tentang reforma agraria pada 24 agustus 2016 yang membahas terkait masyarakat pedesaan, masalah kemiskinan, ketimpangan dan sulitnya lapangan pekerjaan adalah problem pokok dan mendasar yang dihadapi oleh masyarakat. ${ }^{18}$ Pada arahan Joko Widodo memerintahkan untuk melakukan percepatan reforma agraria dengan mewujudkan keadilan dalam penguasaan, pemilikan, penggunaan dan pemanfaatan tanah dan sumber daya alam yang ada di Indonesia.

15 Mia Siscawati, Masyarakat Adat Dan Perebutan Penguasaan Hutan, Wacana Jurnal Tranformasi Sosial. Nomor 33, 2014.

16 M Nazir Salim and Westi Utami, supra no. 6, hlm 45

17 Kantor Staf Presiden, Pelaksanaan Reforma Agraria, Arahan Kantor Staf Presiden: Prioritas Nasional Reforma Agraria Dalam Rencana Kerja Pemerintah Tahun, 2017

18 Id. 
Tantangan yang harus dilalui Joko Widodo-Jusuf Kalla pada awal periode yaitu membentuk kerjasama pemerintah provinsi dan kabupaten/kota dalam memberikan penguatan kepada masyarakat untuk memperbaiki tata guna tanah sehingga dapat mendorong produktivitas para petani. Adanya penguatan kepada masyarakat yang menuntut Joko Widodo-Jusuf Kalla untuk dapat menyelesaikan konflik agraria terdahulu maupun konflik agraria yang akan datang. Arahan presiden dalam menuntaskan masalah kemiskinan di pedesaan tentunya melaksanakan perhutanan sosial menyediakan akses bagi rakyat dalam pengelolaan dan pemanfaatan atas lahan di atas kawasan hutan negara. Pemerintahan Joko Widodo-Jusuf Kalla menyadari realisasi perhutanan sosial baik melalui skema hutan kemasyarakatan, hutan desa, hutan tanaman rakyat, kemitraan, dan hutan adat masih belum secara optimal dengan melihat beberapa konflik agraria yang masih terjadi hingga saat ini. Hutan tanaman rakyat seluas 5,4 juta ha yang sampai tahun 2014 sebagaimana realisasi pencadangan areal lahan hanya mencapai 702.520 hektar (13\%), sedangkan ijin hutan tanaman rakyat yang diterbitkan oleh beberapa Bupati hanya mencapai 188.649 ha. Hutan desa dan hutan kemasyarakatan ditargetkan seluas 2,5 juta hektar dalam RPJMN 20092014, namun realisasinya sampai tahun 2014 hanya mencapai 610.693 ha $(24,45 \%) \cdot{ }^{19}$

Pemerintah yang berencana melaksanakan reformasi agraria sebagai salah satu agenda utama nawacita melaui program redistribusi lahan sebanyak 9 juta hektar bersumber dari lahan Badan Pertanahan Nasional Program yang dicanangkan tahun 2015 ini dinilai cukup lambat sebagaimana realisasi dari target yang ditetapkan sebesar 9 juta hektar (redistribusi tanah seluas 4,5 juta ha dan sertifikasi tanah seluas 4,5 juta ha) di tahun 2015 legalisasi hanya terealisasi sebanyak 836.921 bidang \pm 188.307 ha dan redistribusi tanah hanya sebanyak 90.829 bidang \pm 63.985 ha sementara ditahun 2016 tanah yang berhasil di redistribusikan hanya sebesar 175.000 bidang \pm 123.280 ha (kerjanyata.id). Dalam catatan Badan Musyawarah Tani Indonesia (BAMUSTANI), sepanjang tahun 2016 tidak ada redistribusi lahan yang dilakukan oleh pemerintah dan

19 Id. 
Penetapan lahan terlantar serta tanah negara sebagai objek land reform juga tidak terlihat hasilnya sama sekali sehingga target pemerintah untuk meredistribusi lahan seluas 1,09 juta bidang atau seluas 2,18 juta hektar pada tahun 2016, tidak terlaksana. ${ }^{20}$

Masalah redistribusi lahan bukanlah masalah yang sederhana, karena sering timbul konfik yang berkaitan dengan lahan salah satunya terjadi akibat ketidakjelasan status tanah dan tumpang tindihnya peraturan di lapangan. Sepanjang tahun 2016 dari total luas lahan 1.265.027,39 ha, terjadi konflik agraria yang berdampak pada 86.745 kepala keluarga (KK) dan terjadi sebanyak 450 konflik di antaranya beberapa kelompok seperti warga dan swasta, warga dan pemerintah, antar warga, warga dengan BUMN, maupun TNI dan Polri. ${ }^{21}$

Kebijakan reforma agraria pemerintahan Joko Widodo-Jusuf Kalla melalui nawacita ke-5 dan proyek strategis nasional redistribusi tanah seluas 9 juta hektar bagi petani sesungguhnya telah memberikan harapan baru atas masa pemerintahan sebelumnya. Kebijakan reforma agraria ini tentunya mengarah pada perbaikan hidup masyarakat yang berkeadilan untuk kesejahteran masyarakat. Tindak lanjut dari pada reforma agraria pada intinya adanya pembaharuan agraria sebagai upaya perubahan struktural yang paling mendasardengan memperbaiki hubungan antar subjek-subjek agraria terhadap akses penguasaan dan pemanfaatan objek-objek agraria. Secara nyata bahwa pembaharuan agraria diarahkan untuk melakukan perubahan struktur penguasaan tanah dan perubahan jaminan kepastian penguasaan tanah bagi rakyat dengan memanfaatkan tanah dan kekayaan alam yang menyertainya. ${ }^{22}$

Keberlanjutan reforma agraria di periode kedua Joko Widodo-Ma'aruf Amin tentunya menjalankan program yang belum terselesaikan dimasa periode sebelumnya sehingga masih banyak hal yang perlu diselesaikan oleh Joko WidodoMa'aruf Amin mulai dari pembagian sertifikat yang masih menjadi prioritas kebijakan. Untuk melaksanakan reforma agrarian tentunya ada beberapa yang

20 Ade Nurul Aida, Redistribusi Lahan Di Indonesia Untuk Kesejahteraan Petani, Buletin APBN, Volume II , Edisi 6, hlm 3-13, April 2017

21 Id.

22 Ida Nurlinda, Prinsip-Prinsip Pembaruan Agraria: Perspektif Hukum, Rajawali Pres, Jakarta, 2009, hlm. 7 
perlu diselesaikan terutama konflik agaria yang sering terjadi di beberapa daerah. Perjalanan panjang reforma agraria tentunya mengalami situasi yang berbedabeda sehingga pelaksanaan reforma agraria sejak disusunnya Undang-Undang Pokok Agraria dengan kebijakan pertanahan yang proo poor land policy dan adanya inisiatif gerakan rakyat untuk menuntut reforma agraria dapat diselesaikan. Pasca reformasi persoalan pelaksanaan reforma agraria dihadapkan dengan kondisi baru atas bergulirnya kapitalisme kontemporer yang berwujud atas sistem politik ekonomi neo-liberalisme yang semakin kokoh. Deskripsi secara singkat bahwa pemaknaan pada pelaksanaan reforma agraria dapat diperiksa ulang bagaimana perjalanan idealnya dan praktik praktis sehingga reforma agraria di Indonesia lebih banyak pada kebijakan yaitu Larasita dan Prona. Pada praktiknya kebijakan reforma agrarian akan hanya berfokus pada kebijakan pembagian sertifikat kepada masyarakat sehingga maka situasi ini akan menjadikan tantangan yang kontemporer untuk mewujudkan reforma agraria yang sejalan dengan cita-cita reforma agraria tersebut.

Pelaksanaan reforma agraria dari masa ke masa pemerintahan presiden hingga saat ini dengan beberapa konflik agraria yang masih terjadi tentunya memberikan tantangan bagi pemerintah sebagaimana reforma agraria bagian dari amanah konstitusi. Kehadiran negara dalam memberikan kesejahteraan kepada masyarakat merupakan hal yang mutlak yang harus di jalankan sehingga amanah dari konstitusi untuk kesejahteraan dan kemamkuran rakyat dapat terlaksana dengan baik melalui reforma agraria. Reforma agraria akan selalu tumbuh berkembang sejalan dengan pemerintahan yang selalu berganti meskipun pada praktiknya akan menemukan kekurangan dalam implementasi reforma agraria.

\section{Reforma Agraria Bagian Dari Amanah Konstitusi}

Sejak diundangkannya Undang-Undang Pokok Agraria maka reforma agraria menjadi hal yang harus dilaksanakan negara untuk mewujudkan masyarakat yang adil dan makmur berdasarkan Pancasila. Pasal 33 UndangUndang Dasar Negara Republik Indonesia Tahun 1945 merupakan dasar dalam setiap penyusunan kebijakan terhadap pokok-pokok agraria. Penjelasan Pasal 2 ayat 3 Undang-Undang Pokok Agraria memberikan makna bahwa untuk 
menciptakan sebesar-besar kemakmuran rakyat dengan tetap menjung tinggi nilai kebangsaan, kesejahteraan, dan kemerdekaan dalam masyarakat. Kebebasan yang diterima oleh masyarakat tentunya menjadi cita-cita bangsa Indonesia sebagai negara hukum yang berdaulat, adil dan makmur. Pelaksanaan reforma agraria menjadi bagian tanggung jawab pemerintah baik ditingkat pusat hingga di tingkat daerah yang bertujuan untuk memastikan terlaksananya amanah konstitusi negara dalam menciptakan iklim kesejahteraan dan kemakmuran bagi masyarakat.

Pasal 33 Ayat (3) Undang-Undang Dasar Negara Republik Indonesia Tahun 1945 dengan dua amanah konstitusi yaitu konsep dikuasai dan konsep dipergunakan. Konsep dikuasai yaitu setiap kebijakan yang dikeluarkan oleh pemerintah dalam mengelola sumber daya alam mulai dari tindakan pengurusan, pengaturan, pengelolaan, hingga pengawasan dalam konsep menguasai terhadap bumi, air, dan kekayaan alam untuk kemakmuran rakyat. Konsep dipergunakan yaitu bentuk tanggung jawab negara dalam pemanfaatan sumber daya alam secara merata sehingga rakyat ikut berpartisipasi dalam penentuan atas manfaat sumber daya alam sehingga penghormatan atas keberadaan sumber daya alam secara turun temurun secara berkeadilan. Amanah yang diberikan kepada negara untuk menjalankan setiap urusan yang berhubungan dengan tanah dijelaskan dalam Pasal 6 Undang-Undang Pokok Agraria bahwa semua hak atas tanah mempunyai fungsi sosial dan setiap kegiatan yang berbentuk sosial tidak merugikan kepentingan umum maka kepemilikan dan penguasaan tanah yang melampaui batas tidak diperkenankan.

Reforma agraria yang dimulai pada masa orde lama hingga reformasi yang sampai saat ini tetap dilanjutkan oleh pemerintahan Joko Widodo- Ma'aruf Amin semakin memberikan tantangan untuk melanjutkan misi pelaksanaan reforma agrarian. Kebijakan reforma agraria tidak terlepas dari adanya ketimpangan dalam pemilikan dan penguasaan tanah yang semakin jelas. Ketimpangan ini diakibatkan tidak meratanya pendistribusian tanah sehingga tanah-tanah tersebut terakumulasi di tangan orang atau badan-badan tertentu. Namun di satu sisi ada beberapa sekelompok masyarakat kecil yang kesulitan mencari tanah untk 
bercocok tanam maka dari itu cita-cita atas Undang-Undang Pokok Agraria untuk mewujudkan tatanan tanah nasional untuk kepentingan rakyat. ${ }^{23}$

Timbulnya pelaksanaan reforma agraria yang dilatar belakangi oleh kebutuhan tanah yang semakin beragam sehingga reforma agraria sebagai landasan penting dalam penyusunan kebijakan nasional. Penataan kembali struktur penguasaan hingga pemanfaatan tanah yang lebih berkeadilan akan memberikan manfaat terhadap pelaksanaan reforma agraria. Permasalahan pertanahan tidak hanya menyangkut akses seseorang untuk dapat memiliki sebidang tanah akan tetapi lebih kepada persoalan penghargaan atau penggantian terhadap harga jual yang sesuai atas kepemilikan tanah yang dipindahtangankan baik masyarakat kepada masyarakat sebagai pemilik modal ataupun masyarakat kepada pemerintah yang menggunakan tanah tersebut untuk tujuan pembangunan. Pembangunan yang dilaksanakan pemerintah sebagai salah satu aspek yang diprioritaskan dalam kerangka meningkatkan kesejahteraan rakyat akan tetapi pada kenyataannya seringkali menimbulkan konflik yang berujung pada sengketa kepemilikan tanah. Sumber agraria yaitu tanah sebagai sumber produksi masyarakat untuk dapat memenuhi kebutuhan sehari-hari. Pertambahan jumlah penduduk dan kebutuhan yang semakin banyak juga akan berdampak pada ketidakseimbangan antara masyarakat dan luasan tanah yang tidak pernah bertambah. $^{24}$

Pada program pengaturan, penataan, dan pemanfaatan tanah akan berdampak pada sistem administrasi yang merupakan bagian dari penataan tertib hukum pertanahan. Dalam rangka penataan tertib hukum pertanahan ini hal yang perlu dipahami bahwa terdapat perbedaan pendekatan yang dilakukan terkait penataan hukum pertanahan hanya mengedepankan aspek ekonomi dari tanah tersebut sebagai nilai ekonomis. Pada Garis Besar Haluan Negara di tahun 1999 menjelaskan bahwa pendekatan penataan tanah tidak lagi semata-mata menggunakan pendekatan aspek ekonomi namun memperhatikan aspek-aspek lain termasuk aspek pembangunan di bidang hukum.

23 St Nurjannah, Undang-Undang Pokok Agraria (UUPA) Sebagai Induk Landreform, Al Daulah: Jurnal Hukum Pidana Dan Ketatanegaraan, Nomor 2, Volume 3, hlm 193-205, Desember 2014

24 Mukmin Zakie, Konflik Agraria Yang Tak Pernah Reda, Legality: Jurnal Ilmiah Hukum Volume 24, Nomor 1 , hlm 40-55, Maret 2016 
Amanah konstitusi terkait reforma agraria yang saat ini dilaksanakan sepenuhnya masa pemerintahan Joko Widodo-Ma'aruf Amin merupakan langkah awal periode kedua masa kepemimpinan Joko Widodo. Pada masa sebelumnya genap satu periode pemerintahan Joko Widodo di akhir tahun 2019 merupakan tahun pembuktian keseluruhan janji nawa cita sebagaimana dari sembilan program nawa cita pada masa pemerintahan Joko Widodo-Jusuf Kalla yang telah menjanjikan 9 (sembilan) janji politik utama atau lazim disebut sebagai nawa cita. Janji yang diberikan oleh Joko Widodo-Jusuf Kalla merupakan jalan untuk perubahan dimana Joko Widodo-Jusuf Kalla dengan memasukkan agenda reforma agraria pada janji ke 5, yaitu meningkatkan kualitas hidup manusia Indonesia melalui peningkatan kualitas pendidikan dan pelatihan dengan program Indonesia Pintar serta peningkatan kesejahteraan masyarakat dengan program Indonesia Kerja dan Indonesia Sejahtera dengan mendorong land reform dan program kepemilikan tanah seluas 9 hektar dan program rumah kampung deret atau rumah susun murah yang disubsidi serta jaminan sosial untuk rakyat di tahun 2019. Titik fokus pada masa pelaksanaan reforma agraria saat ini yang telah menetapkan target tanah obyek reforma agraria (TORA) dengan target seluas 9 juta hektar dan kawasan hutan untuk perhutan sosial seluas 12,7 Ha. Input dari kebijakan reforma agraria atas TORA yaitu:

a. Legalisasi aset (4,5 juta Hektar/23 juta sertifikat yang terdiri dari penyerahan sertifikati tanah rakyat melalui program pendaftaran tanah sistematik lengkap (PTSL) seluas 3,9 juta hektar dan sertifikasi tanah transmigrasi seluas 0,6 jt hektar

b. Redistribusi aset (4,5 juta hektar) yang terdiri dari ex-hak guna usaha dan tanah telantar $(0,4$ juta hektar $)$ dan pelepasan kawasan hutan $(4,1$ juta hektar $)$

c. Perhutani sosial (12,7 juta hektar) dengan legalisasi asset atas pemberian akses pengusahaan hutan dalam periode tertentu baik lahan perhutani wilayah jawa maupun lahan di luar jawa.

d. Moratorium/peremajaan sawit dengan melakukan evaluasi pelepasan kawasan hutan untuk kebun yaitu penundaan pelepasan bagi permohonan baru/tidak lengkap/tidak ada persetujuan prinsip, evaluasi atas pelepasan yang sudah 
terbit, dan pelepasan kebun sawit rakyat sepanjang memenuhi persyaratan dalam rangka peremajaan sawit rakyat. 25

Tujuan dari kebijakan pertanahan nasional selama ini mendukung kebijakan makro ekonomi nasional yang hanya mengejar pertumbuhan ekonomi semata tanpa didasari pada penataan aset produksi untuk meningkatan produktivitas. Tujuan pembangunan ekonomi yang diarahkan untuk mendorong pertumbuhan ekonomi yang lebih tinggi akan meningkatkan kesejahteraan rakyat (trickle down effect). ${ }^{26}$ Perjalanan reforma agraria atas amanah konstitusi harus dijalankan sesuai dengan cita-cita bangsa untuk mensejahterahkan masyarakat secara menyeluruh sehingga pelaksanaan reforma agraria tetap pada satu tujuan untuk menyelesaikan ketimpangan atas kepemilikan lahan dan penyelesaian konflik agraria.

\section{Kebijakan Reforma Agraria Saat Ini: Masa Kepemimpinan Dua Periode Joko Widodo.}

Babak baru kebijakan reforma Agraria dimulai dengan terpilihnya Joko Widodo sebagai presiden dan Jusuf Kalla sebagai wakil presiden pada 2014 di dalam nawa cita memuat agenda reforma agraria dan strategi pembangunan Indonesia dari pinggiran yang dimulai dari daerah dan desa. Sembilan agenda prioritas atau yang dikenal sebagai nawacita disebutkan pembenahan agraria yaitu menjamin kepastian hukum hak kepemilikan tanah, penyelesaian sengketa tanah dan menentang kriminalisasi penuntutan kembali hak tanah masyarakat sehingga guna meningkatkan kualitas hidup manusia Indonesia hal ini dilakukan dengan cara mendorong land reform dan program kepemilikan tanah 9 juta hektar. ${ }^{27}$ Program kerja yang dikenal dengan nawacita ini model pemerintahan yang dilakukan oleh Presiden Joko Widodo pada konsepnya hamper sama pada masa pemerintahan Soekarno dimana keinginan Soekarno yaitu menginginkan

25 Disampaikan Dalam Rapat Kerja Project Coordination Committee Program Percepatan Reforma Agraria Asisten Deputi Tata Kelola Kehutanan Samarinda, 20 Februari 2020

26 Ida Nurlinda, Perolehan Tanah Obyek Reforma Agraria (Tora) Yang Berasal Dari Kawasan Hutan: Permasalahan Dan Pengaturannya, Veritas et Justitia, Nomor 2, Volume 4, hlm 252-73, Desember 2018.

27 Ahmad Nashih Luthfi, Reforma Kelembagaan Dalam Kebijakan Reforma Agraria Era Joko Widodo-Jusuf Kalla, BHUMI: Jurnal Agraria Dan Pertanahan, Nomor 2, Volume 4, hlm 140-63, November 2018. 
Indonesia menjadi macan asia dan menjadi negara besar yang ditakuti oleh negara-negara lain di dunia melalui kebijakan yang dibuat oleh pemerintah.

Salah satu metode pendekatan yang dilakukan oleh Joko Widodo-Jusuf Kalla yaitu dengan turun langsung ke masyarakat untuk melihat secara langsung keadaan rakyat serta melihat secara langsung hasil kerja dari para jajaran kabinetnya. Reformasi sistem dan penegakan hukum adalah bagian dari kebijakan pemerintah dalam bidang hukum untuk memberikan kepastian hukum, keadilan dan kemanfaatan bagi masyarakat serta penataan terhadap penguasaan tanah dan tanah secara berkeadilan. ${ }^{28}$ Pelaksanaan reforma agraria selama masa kepemimpinan Joko Widodo-Jusuf Kalla sebelum masa peralihan pada periode kedua terdapat beberapa tantangan dalam pelaksanaan reforma agraria yaitu : 29

1. Peningkatan koordinasi antar kementerian/lembaga terutama dalam rangka redistribusi tanah obyek reforma agraria yang bersumber dari kawasan hutan dan tanah transmigrasi yang belum bersertifikat;

2. Operasionalisasi perangkat kelembagaan yang telah diamanatkan di dalam Peraturan Presiden Nomor 86 Tahun 2018 tentang Reforma Agraria berupa Gugus Tugas Reforma Agraria tingkat Nasional, Provinsi dan Kabupaten;

3. Penguatan komitmen pemerintah daerah dalam mendukung percepatan reforma agraria terutama pada aspek identifikasi subyek reforma agraria;

4. Penjajakan kerja sama dengan kementerian/lembaga dan badan usaha dalam rangka pelaksanaan pemberdayaan masyarakat penerima tanah obyek reforma agraria.

Pada rencana pembangunan jangka menengah nasional (RPJMN) 20152019 menyatakan bahwa pemerintahan Joko Widodo-Jusuf Kalla akan mendorong land reform dan program kepemilikan tanah seluas 9 juta hektar. Tujuan dalam program kepemilikan tanah seluas 9 juta hektar yaitu untuk mengatasai ketimpangan kepemilikan tanah bagi masyarakat terutama masyarakat yang bertumpu pada lahan pertanian. Penyediaan lahan untuk pertanian menjadi fokus

28 Niluh Ariningsih Sari, I Wayan Suwanda, Kebijakan Di Era Pemerintahan Joko Widodo Dan Jusuf Kalla (Perspektif Politik Hukum Dan Agraria), Ganec Swara, Nomor 2, Volume 13, hlm 237-43 September 2019.

29 Disampaikan pada Rapat Kerja Project Coordination Committee Program Percepatan Reforma Agraria Asisten Deputi Tata Kelola Kehutanan Samarinda, 20 Februari 2020 
pemerintah untuk menyediakan lahan dalam rangka meningkatkan efektifitas tanah bagi kesejahteraan masyarakat.

Arahan Presiden Joko Widodo dalam reforma agraria pada masa pemerintahan periode pertama yaitu mengatasi ketimpangan, kemiskinan dan penyelesaian konflik agraria. Intruksi Joko Widodo dengan melaksanakan percepatan reforma agraria dengan melakukan redistribusi lahan pada masyarakat yang tidak memiliki lahan untuk bertani dan menyelesaikan konfik agraria yang sedang terjadi merupakan bagian tugas dari Kementerian Agraria dan Tata Ruang/ Badan Pertanahan Nasional. Dalam optimalisasi terhadap ketepatan program reforma agraria pemerintah melakukan sosialiasi terhadap program percepatan reforma agraria berdasarkan meningkatnya kebutuhan tanah yang semakin beragam sehingg perlu adanya pengaturan kerangka hukum yang mengatur penggunaan tanah dengan reforma agraria sebagai landasan penting dalam penyusunan kebijakan nasional atas bagian dari nawacita. ${ }^{30}$ Masa pemerintahan Joko Widodo-Jusuf Kalla dengan membangun infrastruktur secara besar-besaran membuat sistem perizinan semakin mudah untuk di dapatkan dengan cakupan penguasaan lahan berskala besar. Skema kebijakan Joko Widodo-Jusuf Kalla atas terbukanya investasi secara besar-besaran memberikan skema objek reforma agraria yaitu legalisasi aset, redistribusi aset, dan legalitas akses. Skema ketiga objek reforma agrari menjadi parameter utama pemerintah untuk menjalankan reforma agraria. Tahapan legalisasi aset menjadi perdebatan akibat ketidaksesuain program reforma agraria dengan redistribusi aset yang ternyata legalisasi aset tidak memiliki substansi yang cukup untuk menata ketimpangan, kepemilikan, dan penguasaan tanah bagi masyarakat Indonesia.

Proses percepatan program reforma agraria hingga februari 2020 dengan dikeluarkannya sertifikat seluas 5,88 juta ha atau sekitar 65\% dari target RPJMN seluas 9 juta ha lahan. Untuk legalisasi aset dikeluarkannya sertifikat seluas 5,05 juta ha atau sekitar $112 \%$ dari target RPJMN seluas 4,5 juta ha. Sedangkan untuk redistribusi aset dikeluarkannya sertifikat seluas 0,795 juta ha atau sekitar $18 \%$ dari target RPJMN seluas 4,5 juta ha. Percepatan realisasi penerbitan sertifikat

30 Disampakan dalam Konsultasi Publik, Program Percepatan Reforma Agararia, Samarinda 20 Februari 2020. 
reforma agraria sangatlah dibutuhkan terutama untuk tanah objek reforma agraria yang bersumber dari kawasan hutan dan tanah transmigrasi. ${ }^{31}$

Grafik 1: Realisasi Reforma Agraria

\section{Realisasi Reforma Agraria (Ha)}

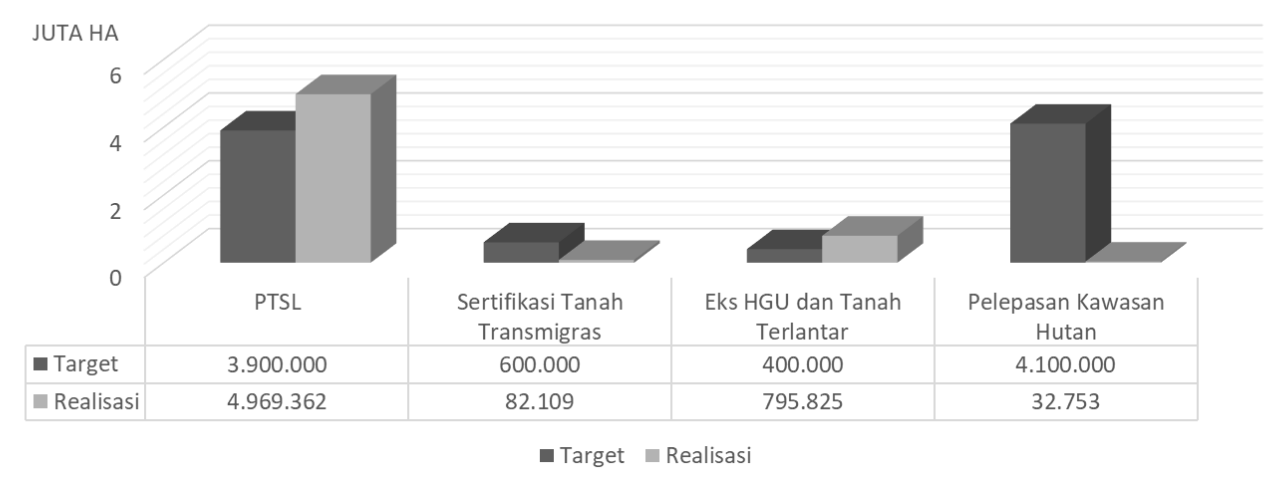

Sumber: Kementerian ATR/BPN dan KLHK

Hasil persentase dari target realisasi reforma agraria diketahui bahwa masih banyak yang harus dilakukan pemerintah yang didasari adanya target yang belum terselesaikan. Periode kedua Joko Widodo adalah pembuktian seutuhnya mengenai realisasi reforma agraria sebagai pembuktian atas janji yang diberikan kepada masyarakat untuk melaksanakan reforma agrarian dan menyelesaikan konflik agraria. Pelaksanaan reforma agraria tidak hanya memberikan sertifikat secara aktif kepada masyarakat namum adanya tindak lanjut dari penyerahan sertifikat berdasarkan manfaat yang diperoleh oleh masyarakat. Penyelesaian konflik agraria juga menjadi hal yang penting untuk diselesaikan pada masa pemerintahan kedua Joko Widodo dengan melihat hasil kinerja lima tahun sebelumnya bahwa telah terjadi 2.047 kejadian konflik agraria di seluruh sektor. Data konflik sepanjang lima tahun tersebut juga menunjukkan dominasi sektor perkebunan sebagai penyumbang konflik tertinggi yaitu sebanyak 729 (35,5 \%), sektor properti 499 konflik, pembangunan infrastruktur 369, konflik pertanian

31 Disampaikan dalam Rapat Kerja Project Coordination Committee Program Percepatan Reforma Agrariaasisten Deputi Tata Kelola Kehutanan Samarinda, 20 Februari 2020 
145, kehutanan 118, pertambangan 117, pesisir dan pulau-pulau kecil sebanyak 60 letusan konflik, dan fasilitas militer 10 letusan konflik. ${ }^{32}$

Pelaksanaan reforma agraria dengan program nawacita selama periode Joko Widodo-Jusuf Kalla maupun Joko Widodo-Ma'aruf, maka tidak banyak tuntutan rakyat pada Pada periode kedua dari Joko Widodo- Ma'aruf Amin yaitu menindaklanjuti program reforma agraria yang belum tercapai salah satunya mengatasi ketimpangan kepemilikan lahan dan menyelesaiakan konflik agraria. Realisasi dari pelaksanaan reforma agraria yang sudah dilaksanakan hingga tahun 2019 tentunya masih banyak yang harus diselesaikan oleh Joko Widodo-Ma'aruf Amin sebagaimana baru dimulainya masa pemerintahan periode kedua yang melahirkan Undang-Undang Nomor 11 Tahun 2020 tentang Cipta Kerja atau yang disebut Omnibus Law.

Lahirnya Undang-Undang Nomor 11 Tahun 2020 tentang Cipta Kerja atau yang disebut Omnibus Law memberikan catatan terhadap pelaksanaan reforma agraria. Beberapa hal-hal yang berkaitan dengan reforma agraria salah satunya pengadaan tanah dan pembentukan bank tanah. Kehadiran Undang-Undang Nomor 11 Tahun 2020 tentang Cipta Kerja yang berkaitan dengan reforma agraria akan membentuk kepentingan bagi korporasi dan akan menimbulkan pelanggaran hak bagi masyarakat petani yang berada di wilayah pedesaan. Keberadaan bank tanah yang menunjukan ketidak adilan bagi masyarakat akibat adanya bank tanah yang sebagai bagian dalam proses pembangunan dengan pengadaan tanah bagi kepentingan investasi Kawasan Ekonomi Khusus (KEK), real estate, pariwisata, bisnis properti, pembangunan infrastruktur yang bersifat lapar. ${ }^{33}$

Upaya pelaksanaan reforma agraria setelah berakhirnya tahun 2019 membuka gerbang untuk memulai tahun 2020 dengan beberapa agenda yang belum terselesaikan maupun yang akan diselesaikan secepat mungkin selama periode Joko Widodo-Ma'aruf. Secara khusus perlunya pertimbangan setiap proses pembangunan yang membuka investor untuk melakukan investasi di Negara

32 Catatan Akhir Tahun 2019 Konsorsium Pembaruan Agraria "Dari Aceh Sampai Papua: Urgensi Penyelesaian Konflik Struktural dan Jalan Pembaruan Agraria ke Depan”

33 http://kpa.or.id/media/baca2/siaran_pers/150/Atas_Nama_Pengadaan_Tanah_Untuk_ Kemudahan_Investasi_Omnibus_Law_Cipta_Kerja_Bahayakan_Petani_dan_Masyarakat_Adat/ diakses tanggal 25 Februari 2020, pukul 12.00 Wita 
Indonesia. Undang-Undang Cipta Kerja di indikasi adanya beberapa persoalan yang akan timbul akibat tidak sejalannya apa yang dicita-citakan reforma agraria. pada Undang-Undang Cipta Kerja yang pada proses pengadaan tanah bertujuan untuk memberikan ruang dalam pembangunan infrastruktur secara besar-besaran tanpa melihat dampak yang akan dirasakan masyarakat dari pembangunan infrastruktur tersebut. Nilai tanah yang tidak lagi ekonomis bagi masyarakat memberikan pergeseran paradigma bahwa tanah hanya untuk kepentingan pembangunan semata tanpa memperhatikan kebutuhan masyarakat sebagai penunjang kehidupan yang sejahtera.

Keberpihakan pemerintahan dengan para investor dalam pengadaan tanah juga sebagai bagian dari dipermudahnya alokasi pengadaan tanah secara cepat tanpa memperhitungkan dampak yang akan terjadi. Reforma agraria dengan tujuan akhir terhadap penataan dan penguasaan tanah secara berkeadilan tentunya akan terlihat dari adanya transparansi pemerintah dan investor kepada masyarakat melalui Undang-Undang Cipta Kerja. Setiap kebijakan yang dikeluarkan oleh pemerintah seharunya dilaksanakan evaluasi secara berkala dan monitoring terhadap pelaksanaan program reforma agrarian sebagai bagian tolak ukur mengenai tingkat keberhasilan dalam pelaksanaan reforma agraria. UndangUndang Cipta Kerja yang berkaitan dengan adanya reforma agrarian apabila memberikan dampak yang tidak berkeadilan bagi masyarakat juga harus menjadi bahan evaluasi bagi pemerintahan Joko Widodo-Ma'aruf.

Perjalanan reforma agraria dari masa ke masa akan selalu menjadi pembanding atas cita-cita yang diinginkan oleh reforma agraria. Penataan kembali struktur atas kepemilikan tanah yang lebih berkeadilan adalah tujuan yang mendasar agar terciptanya kemakmuran rakyat Indonesia. Untuk itu pelaksanaan reforma agraria harus dilaksanakan seoptimal mungkin oleh seluruh jajaran Kementerian Agraria Tata Ruang/Badan Pertanahan Nasional di pusat dan daerah sesuai dengan aturan kebijakan yang menunjang atas terlaksananya reforma agrarian. Tugas utama gugus tugas percepatan reforma agraria tentunya menyelesaikan tanah objek reforma agrarian untuk diberikan kepada masyarakat yang membutuhkan. Menelusuri perjalanan reforma agrarian ditahun 2021 tentunya tidak hanya sekedar kebijakan terkait pelaksanaan reforma agraria 
namun harus adanya titik akhir yang memberikan kepastian kepada masyarakat untuk terjaminnya rasa keadilan dan meningkatnya kesejahteraan masyarakat seluas-luasnya. Kepekaan Joko Widodo dan menuntaskan janji kepada masyarakat merupakan kunci untuk menyelesaikan apa yang dikehendaki masyarakat kepada pemerintah saat ini terutama terkait dalam mengatasi ketimpangan kepemilikan lahan dan penyelesaian konflik agraria.

Beberapa hal yang harus diperhatikan oleh pemerintahan saat ini adalah lebih mengedepankan aspek kemanusiaan yang dalam hal ini terkait penyelesaian konflik agraria akibat ketimpangan pemilikan lahan antara masyarakat dan investor. Pelaksanaan reforma agraria yang hingga saat ini masih terus berlangsung pada kenyataannya pemerintah masih terus melakukan pemetaan terhadap lahan 9 jt hektar dan pemerintah terlalu fokus dalam pembangunan secara besar-besaran sehingga akan berdampak terhadap kepemilikan lahan yang lebih dominan dimiliki oleh investor. Hambatan pelaksanan reforma agraria saat ini terlalu banyak aturan/regulasi yang tidak terfokus sehingga memberikan kesan tidak efektifnya aturan tersebut dalam menyelesaikan konflik agraria atas ketimpangan kepemilikan tanah. Reforma agraria dikategorikan berhasil dapat tergambarkan dengan penyelesaian ketimpangan kepemilikan tanah sehingga hadinya keadilan bagi pemilik tanah bukan ketidakadilan antara satu orang memiliki banyak tanah dengan satu orang yang tidak memiliki tanah sama sekali. Reforma agraria tetap berpedoman pada prinsip yang utama bahwa tanah diberikan kepada mereka yang membutuhkan dan tanah mempunyai fungsi sosial sehingga perwujudan keadilan dan mengurangi ketidakmerataan terhadap tanahtanah di Indonesia dapat terlihat secara nyata.

\section{Penutup}

Dalam kajian artikel ini memberikan kedudukkan tersendiri terhadap perjalanan reforma agraria dari masa Sukarno hingga Joko Widodo. Permulaan reforma agraria di era sukarno dengan lahirnya Undang-Undang Pokok Agraria sebagai dasar hukum yang berkaitan dengan sumber-sumber agraria. Masingmasing periodesasi era presiden ini yang paling lama menduduki jabatan presiden adalah Suharto sebagai bapak pembangunan. Pembangunan secara besar-besaran 
akan berdampak pada nilai ekonomis tanah bagi masyarakat sebagaimana semakin banyak tanah yang dipergunakan untuk pembangunan maka masyarakat semakin kecil mendapatkan peluang untuk memperoleh tanah. Masa reformasi sebagai bagian awal untuk memperbaiki konsep yang dicita-citakan reforma agraria mengatasi ketimpangan kepemilikan lahan dan penyelesaian konflik agrarian. Keberlanjutan reforma agraria melalui bebarapa kebijakan pemerintah di masing-masing periode kepemimpinan presiden sesungguhnya untuk menciptakan kebijakan nasional yang bertujuan untuk pembangunan secara merata di seluruh wilayah Indonesia. Hal yang dilakukan dalam program reforma agraria saat ini adalah melakukan penataan aset dan akses sehingga penafsiran dari reforma agraria seutuhnya tidak hanya memberikan sertifikat kepada masyarakat semata, namun seberapa besar dampak setelah diberikannya sertifikat tersebut kepada masyarakat sebagai nilai tambah ekonomis atas tanah yang dimiliki. Laju perkembangan atas sengketa konflik agraria juga bagian yang harus diselesaikan oleh pemerintah sebagai tindak lanjut amanah konstitusi.

Amanah dari konstitusi yang tertuang dalam Pasal 33 UUD NRI 1945 menjelaskan bahwa negara harus menjamin kesejahteraaan masyarakat seluasluasnya. Terjadinya Ego sektoral untuk membangun secara besar-besaran tanpa memperhatikan rakyat tentunya akan menghasilkan pekerjaan rumah untuk pemerintahan selanjutnya, Lahirnya Undang-Undang Nomor 11 Tahun 2020 tentang Cipta Kerja (Omnibus Law) menjadi babak baru bagi keberlanjutan reforma agraria yang mengedepankan keadialan dan kesejahteraan berkelanjutan bagi masyarakat. Periode kedua Joko Widodo dengan membuka ruang bagi investor secara besar-besaran akan berdampak pada proses pengadaan tanah dengan memberikan kemudahan untuk memperoleh tanah. Negara sebagai pemegang kekuasaan tertinggi untuk mengatur pemilikan tanah, penggunaan dan pemanfaatan tanah untuk dipergunakan bagi sebesar-besar kemakmuran rakyat. Reforma agrarian yang sedang berlangsung saat ini dengan beberapa kebijakan yang dikeluarkan atas lahirnya Undang-Undang Nomor 11 Tahun 2020 tentang Cipta Kerja (Omnibus Law) menjadi kekhawatiran adanya pergeseran paradigma bahwa keberadaan tanah hanya untuk kepentingan pembangunan semata tanpa 
memperhatikan kebutuhan masyarakat sebagai penunjang kehidupan yang sejahtera dan berkeadilan.

\section{Daftar Pustaka}

Buku:

Budi Harsono, Hukum Agraria Indonesia, Sejarah Pembentukan UUPA, Isi Dan Pelaksanaannya, Jilid I, Citra Aditya Bakti, Bandung, 2003.

Boedhi Wijardjo dan Herlambang Perdana, Reklaiming dan Kedaultan Rakyat, YLBHI, 2001.

Ida Nurlinda, Prinsip-Prinsip Pembaruan Agraria: Perspektif Hukum, Rajawali Pres, Jakarta, 2009.

M Nazir Salim and Westi Utami, Reforma Agraria, Menyelesaikan Mandat Konstitusi: Kebijakan Reforma Agraria Dan Perdebatan Tanah Objek Reforma Agraria, STPN Press,Yogyakarta 2020.

M. Syamsudin, Operasionalisasi Penelitian Hukum, Rajagrafindo Persada, Jakarta 2007.

Noer Fauzi, Land Reform Dari Masa Ke Masa, Tanah Air Beta, Yogyakarta, 2012.

Supriadi, Hukum Agraria, Sinar Grafika, Jakarta, 2007.

Zainuddin Ali, Metode Penelitian Hukum, Sinar Grafika, Jakarta , 2011.

\section{Jurnal:}

Ade Nurul Aida, Redistribusi Lahan Di Indonesia Untuk Kesejahteraan Petani, Buletin APBN, Volume II , Edisi 6, hlm 3-13, April 2017.

Ahmad Nashih Luthfi, Reforma Kelembagaan Dalam Kebijakan Reforma Agraria Era Joko Widodo-Jusuf Kalla, BHUMI: Jurnal Agraria Dan Pertanahan, Nomor 2, Volume 4, hlm 140-63, November 2018.

Ida Nurlinda, Perolehan Tanah Obyek Reforma Agraria (Tora) Yang Berasal Dari Kawasan Hutan: Permasalahan Dan Pengaturannya, Veritas et Justitia, Nomor 2, Volume 4, hlm 252-73, Desember 2018.

Mia Siscawati, Masyarakat Adat Dan Perebutan Penguasaan Hutan, Wacana Jurnal Tranformasi Sosial. Nomor 33, 2014.

Mukmin Zakie, Konflik Agraria Yang Tak Pernah Reda, Legality: Jurnal Ilmiah Hukum Volume 24, Nomor 1, hlm 40-55, Maret 2016.

Niluh Ariningsih Sari, I Wayan Suwanda, Kebijakan Di Era Pemerintahan Joko Widodo Dan Jusuf Kalla (Perspektif Politik Hukum Dan Agraria), Ganec Swara, Nomor 2, Volume 13, hlm 237-43 September 2019.

Retor A W Kaligis, Agrarian Reform As A Nationalism Issue From Colonial To Reformasi Era, Paramita: Historical Studies Journal, Volume 29, Nomor 1, hlm 28-42, Maret 2019.

St Nurjannah,Undang-Undang Pokok Agraria (UUPA) Sebagai Induk Landreform, Al Daulah: Jurnal Hukum Pidana Dan Ketatanegaraan, Nomor 2, Volume 3, hlm 193-205, Desember 2014.

Siti Chadijah, Dwi Kusumo Wardhani, and Ali Imron, Kebijakan Reforma Agraria Terhadap Lahan Pertanian Di Kabupaten Tulungagung, JCH (Jurnal Cendekia Hukum), Nomor 1, Volume 6, hlm : 91-103, September 2020. 
Widiyanto, Potret Konflik Agraria Di Indonesia, BHUMI: Jurnal Agraria Dan Pertanahan, Volume 1, Nomor 37, hlm 15-27, April 2013.

\section{Pustaka tidak dipublikasi:}

Catatan Akhir Tahun 2019 Konsorsium Pembaruan Agraria Dari Aceh Sampai Papua: Urgensi Penyelesaian Konflik Struktural dan Jalan Pembaruan Agraria ke Depan.

Kantor Staf Presiden, "Pelaksanaan Reforma Agraria," Arahan Kantor Staf Presiden: Prioritas Nasional Reforma Agraria Dalam Rencana Kerja Pemerintah Tahun, 2017.

Rapat Kerja Project Coordination Committee Program Percepatan Reforma Agraria Asisten Deputi Tata Kelola Kehutanan Samarinda, 20 Februari 2020.

\section{Website:}

http://kpa.or.id/media/baca2/siaran_pers/150/Atas_Nama_Pengadaan_Tanah_Un tuk_Kemudahan_Investasi_Omnibus_Law_Cipta_Kerja_Bahayakan_Petani_d an_Masyarakat_Adat/ diakses tanggal 25 Februari 2020.

\section{Peraturan Perundang-Undangan:}

Undang-Undang Dasar Negara Republik Indonesia Tahun 1945.

Undang-Undang Nomor 5 Tahun 1960 tentang Peraturan Dasar Pokok-Pokok Agraria.

Undang-Undang Nomor 11 Tahun 2020 tentang Cipta Kerja.

Peraturan Presiden Nomor 45 Tahun 2016 tentang Rencana Kerja Pemerintah Tahun 2017. 